\title{
Oncostatin M-induced genes in human astrocytomas
}

\author{
ANNIKA KRONA, PIERRE ÅMAN, CHARLOTTE ÖRNDAL and AGNETHA JOSEFSSON \\ Lundberg Laboratory for Cancer Research, Department of Pathology, Institute of Biomedicine, \\ Sahlgrenska University Hospital, Göteborg University, Gula stråket 8, 41345 Gothenburg, Sweden
}

Received April 5, 2007; Accepted June 20, 2007

\begin{abstract}
Oncostatin M (OSM) is a member of the interleukin-6 (IL-6) cytokine family and known to be induced in the nervous system as a result of cell stress. OSM is expressed in most human brain tumors, but the effects on tumor cells are unclear. The cytokine is known to activate the JAK/STAT signaling pathway by binding to its receptors gp130/OSMß or gp130/LIFRß and thereby initiating activation or suppression of a number of STAT target genes. The objective of the study was to identify OSM-regulated genes that could help in understanding the function of OSM in glioma cells. The glioma cell line, U1242MG was stimulated by OSM and the gene expression patterns were analyzed by microarray. In total, nineteen differentially expressed genes were selected due to high intensity, level of up/downregulation and biological functions. The differentially expressed genes were verified using quantitative PCR. Additional validation of the confirmed OSM-induced proteins was performed in human astrocytoma tissues by immunohistochemistry. Among the up-regulated genes were CHI3L1, PLAU, MT2A and EPAS1. These genes are known to be involved in cell matrix remodeling, migration, proliferation control and angiogenesis. The results suggest that OSM induces genes that might contribute to the development and progression of astrocytomas.
\end{abstract}

\section{Introduction}

Oncostatin M (OSM) is a multifunctional cytokine shown to be induced in the nervous system as a result of cell stress, as in multiple sclerosis, epileptic seizure and peripheral nerve injury (1-3). Microglia, hypertrophic astrocytes and infiltrating leucocytes are sources of OSM $(4,5)$. We have previously reported that OSM is expressed in human brain tumors and that the production stems from the neoplastic cells, but it remains unclear what effects OSM has in these tumors (6).

Correspondence to: Dr Annika Krona, Lundberg Laboratory for Cancer Research, Department of Pathology, Institute of Biomedicine, Sahlgrenska University Hospital, Göteborg University, Gula stråket 8,413 45 Gothenburg, Sweden

E-mail: annika.krona@1lcr.med.gu.se

Key words: glioma, Oncostatin M, microarray, gene expression, CHI3L1
OSM is a member of the interleukin (IL)- 6 cytokine family which includes IL-6, IL-11, leukemia inhibitory factor (LIF), ciliary neurotrophic factor (CNTF), cardiotrophin-1 (CT-1) and cardiotrophin-like cytokine (CLC) $(7,8)$. These cytokines are involved in the regulation of the acute-phase to injury, infection, haematopoiesis, liver and neuronal regulation, embryonal development and fertility (9). Members of this cytokine family activate the Janus kinase/signal transducer and activator of transcription (JAK/STAT) and the mitogenactivated protein kinase (MAPK) cascades through a common signal-transducing receptor, gp130 in combination with cytokine-specific subunits $(10,11)$. OSM signals through a heterocomplex receptor consisting of the low-affinity leukemia inhibitory factor receptor $\beta$ subunit (LIFRß) and the gp130 signal transducing protein type I receptor (12). A second high-affinity receptor for OSM has been described, in which the LIFR $\beta$ subunit is replaced by the closely related oncostatin $M$ receptor $\beta$ subunit (OSMRß). Binding of OSM to the receptor induces phosphorylation and recruitment of cytoplasmic STAT family members (STAT1 and STAT3) to the nucleus where they bind to specific DNA sequences (13). We have recently shown receptors to be present and the JAK/STAT signaling pathway to be functional in glioma cell lines and cultured glioma cells (14). STAT binding DNA sequences are found near the transcription start site of many genes. To date, many possible target genes for various STATs have been identified, but it is unknown which genes are induced by OSM in brain tumors (15).

In the present study we have used microarray, quantitative PCR (QPCR), Western blotting and immunohistochemistry (IHC) to search for and investigate putative target genes and down-stream effects of OSM in brain tumors.

\section{Materials and methods}

Cell culture and OSM stimulation. Human glioma cell lines, $\mathrm{U} 1242 \mathrm{MG}, \mathrm{U} 343 \mathrm{MG}$ and U1231MG, were cultured at $37^{\circ} \mathrm{C}$ in $5 \% \mathrm{CO}_{2}$ in a humidified incubator. The culturing medium, basal medium Eagle (BME) with Earl's salts (Invitrogen Corporation, Carlsbad, CA) was supplemented with $10 \%$ fetal calf serum, $2 \mathrm{mM}$ L-glutamine, $50 \mathrm{U} / \mathrm{ml}$ penicillin and $50 \mu \mathrm{g} / \mathrm{ml}$ streptomycin was used. Normal human astrocytes, NHA (Clonetics, Walkersville, MD) were obtained and maintained in an astrocyte growth medium bullet kit (Clonetics).

Prior to stimulation, cells were incubated for $24 \mathrm{~h}$ in medium containing $0.5 \%$ fetal calf serum. Recombinant 
human OSM (Sigma-Aldrich, Steinheim, Germany) was added to the cultures to a final concentration of $50 \mathrm{ng} / \mathrm{ml}$, followed by incubation for 4, 14 and $24 \mathrm{~h}$. Unstimulated cells were used as controls. For the array study incubation times were 3,12 and $24 \mathrm{~h}$.

Genome-wide gene expression analysis. Total RNA was extracted from cultured cells using the Trizol method (Invitrogen Life Technologies, Carlsbad, CA). The RNA was further purified using a Qiagen RNeasy kit (Qiagen, Hilden, Germany) and then stored at $-130^{\circ} \mathrm{C}$. Five $\mu \mathrm{g}$ of RNA was used for cDNA synthesis with Cy3 and Cy5 labeled nucleotides. cDNA labeling and hybridization to microarray glasses was performed according to the Pronto! Plus Direct Labeling v1.2 labeling and hybridization kit (In Vitro, Sweden). Microarrays were produced at the Swegene DNA Microarray Resource Center, Department of Oncology, Lund University, Sweden (http://swegene.onk.lu.se). Human array-ready oligonucleotide libraries (version 2.1, cat. no. 810516; and version 2.1.1, cat. no. 810518), comprising approximately 27000 unique probes, were obtained from Operon (Operon Biotechnologies, Germany). Probes were dissolved in Corning universal spotting solution (Corning, Acton, MA) and printed in duplicates on aminosilane-coated glass slides (UltraGAPS, cat. no. C40017, Corning) using a MicroGrid2 robot (BioRobotics, Cambridgeshire, UK) equipped with MicroSpot $10 \mathrm{~K}$ pins (BioRobotics). Following printing, arrays were left in a desiccator to dry for $48 \mathrm{~h}$, rehydrated for $1 \mathrm{sec}$ over steaming water, snap-dried on a hot plate $\left(98^{\circ} \mathrm{C}\right)$, and $\mathrm{UV}$-cross-linked $\left(800 \mathrm{~mJ} / \mathrm{cm}^{2}\right)$.

Image and data analysis. Hybridized microarrays were scanned using an Agilent G2565AA microarray scanner (Agilent Technologies, Palo Alto, CA). Fluorescence intensities were converted to numeric data using Agilent G2567AA feature extraction software (Agilent Technologies), and uploaded into Bio-array software environment (BASE), http://base.thep.lu.se, for further analysis (16). Minimum median intensity was set to 1 to avoid data loss when the ratio between the samples and the reference cell line (unstimulated U1242MG) was being calculated. The LOWESS algorithm (17) was used for normalization. Genes with differences of at least two-fold in signal intensity between OSM-treated U1242MG and control were scored as up- or down-regulated. Genes with a normalized intensity $>75$ were selected. Based on intensity, level of up/down-regulation and the biological function, some of the differentially expressed genes were selected for further study.

Confirmation of array data with quantitative PCR. Total RNA $(5 \mu \mathrm{g})$ was mixed with $2 \mu \mathrm{g}$ of pdT oligomers (Amersham Pharmacia Biotech AB, Uppsala, Sweden) and incubated at $65^{\circ} \mathrm{C}$ for $5 \mathrm{~min}$. First-strand cDNA synthesis was then performed by adding $0.05 \mathrm{M}$ tris- $\mathrm{HCl}, \mathrm{pH} 8.3,0.075 \mathrm{M} \mathrm{KCl}$, $3 \mathrm{mM} \mathrm{MgCl}_{2}, 0.01 \mathrm{M} \mathrm{DTT}, 10 \mathrm{U} / \mu 1 \mathrm{M}-\mathrm{MLV}$ reverse transcriptase (Life Technologies, Grand Island, NY, USA), $0.05 \mathrm{U} / \mu 1 \mathrm{RNA}$ guard (Life Technologies) and $10 \mathrm{mM}$ of each dNTP to a final volume of $20 \mu 1$ and incubating the samples at $37^{\circ} \mathrm{C}$ for $1 \mathrm{~h}$. The reaction was terminated by incubation at $65^{\circ} \mathrm{C}$ for $5 \mathrm{~min}$.
Real-time quantitative PCR (QPCR) was carried out using an ABI Prism 7700 sequence detection system (Applied Biosystems). A volume of $1 \mu 1$ of cDNA, diluted 1:30, was used in a 25- $\mu 1$ PCR reaction of SYBR-Green PCR core reagents (Applied Biosystems). PCR primers (300 nM) were designed by Primer3 (http://frodo.wi.mit.edu/cgi-bin/primer3/ primer3_www.cgi) and are listed in Table I. Primers were designed to span over exon-exon borders to minimize PCR amplification of possible genomic DNA and the sizes of the PCR products were analyzed by agarose gel electrophoresis. $ß$-actin and GAPDH were used as normalization control genes. All samples were run in duplicate. The relative ratios of gene expression were calculated using the following formula (18):

$$
\text { Ratio }=\operatorname{SQR}\left(2^{\left(\mathrm{Ct}(-\mathrm{ACTIN}) * 2^{(\mathrm{Ct} \mathrm{GAPDH})}\right) / 2^{\mathrm{Ct} \text { sample }}}\right.
$$

Search for putative STAT binding sites. Activated STAT molecules are translocated to the nuclei, where they bind to specific DNA sequences that fit the palindrome sequence TTCN $_{(2-4)}$ GAA (19). Searches for putative STAT binding sites in selected genes were performed. We searched the region, 1000 base pairs upstream of the transcription start site, first exon and first intron using the MATCH tool (http://www.generegulation.de/) with the selection set to minimize false negatives.

Western blot analysis. Cells were cultured to $100 \%$ confluence in $25-\mathrm{cm}^{2}$ flasks, lysed in $300 \mu 1$ NuPage LDS sample buffer (Invitrogen, Carlsbad, CA) and sonicated. Proteins were separated on NuPage 4-12\% Bis-Tris gels (Invitrogen) in NuPage MOPS SDS running buffer (Invitrogen) and were then transferred to Immobilon-P transfer membranes (Millipore Corporation, Bedford, MA), probed with respective antibody (primary antibody, $1.5 \mathrm{~h}$; and secondary antibody, $1.5 \mathrm{~h}$ ) and signals were detected using 5-bromo-4-chloro-3-indolyl phosphate/nitro blue tetrazolium (Sigma-Aldrich, Steinheim, Germany). A polyclonal antibody specific for CHI3L1/YKL-40 (Quidel Corp., San Diego, CA) was obtained from Quidel and used at a dilution of 1:500. Monoclonal anti-actin antibody (Santa Cruz Biotechnologies, Santa Cruz, CA) was used at a dilution of 1:200 as a loading control. Secondary antibodies were obtained from Dako (Glostrup, Denmark).

Immunohistochemistry. IHC analysis was performed on sections from seven glioblastoma multiforme (GBM), three anaplastic astrocytomas, one diffuse astrocytoma, three pilocytic astrocytomas and one atypical meningioma. Formaldehyde-fixed tumor specimens were dehydrated, embedded in paraffin wax and cut into 5- $\mu \mathrm{m}$ thick sections. After deparaffinization, tissue sections for CHI3L1 and EPAS1 detection were treated in a microwave oven for antigen retrieval. The sections for PLAU detection were treated for $20 \mathrm{~min}$ with $0.05 \%$ Pronase E in PBS. Sections were then blocked with hydrogen peroxide to prevent endogenous peroxidase activity and with normal rabbit serum to prevent nonspecific staining. The primary antibodies CHI3L1/ YKL-40 (1:100, Quidel Corp.), PLAU/uPA (1:100, Abcam, Cambridge, UK) and EPAS1/HIF2 $\alpha$ (1:1000, Abcam) were applied overnight at $+4^{\circ} \mathrm{C}$. After incubation with the secondary 
Table I. Primer sequences and the product size of selected genes used in QPCR.

\begin{tabular}{|c|c|c|c|}
\hline Gene & Forward $\left(5^{\prime} \rightarrow 3^{\prime}\right)$ & Reverse $\left(5^{\prime} \rightarrow 3^{\prime}\right)$ & Product size (bp) \\
\hline CHI3L1 & TCCCAACACCTGGATTTCAT & CAACATGTACCCCACAGCAT & 153 \\
\hline EPASI & TTGATGTGGAAACGGATGAA & GGAACCTGCTCTTGCTGTTC & 196 \\
\hline GRIK2 & СTCTGGGAGTTCCCCACATA & TGAGCTCTTGCAAACGAATG & 195 \\
\hline ILIRI & CTTGCCTGAGGTCTTGGAAA & CCAGCTGAAGCCTGATGTTT & 160 \\
\hline MAP2K2 & GTGAACGAGCCACCTCCTAA & GGCAAAATCCACTTCTTCCA & 165 \\
\hline MT2A & GCAAATGCAAAGAGTGCAAA & ATCCAGGTTTGTGGAAGTCG & 186 \\
\hline$P L A U$ & TGTGAGATCACTGGCTTTGG & GTCAGCAGCACACAGCATTT & 156 \\
\hline RECK & CCGAGTGTGCTTCTGTCAAG & GCATGCGGATTTTCTGAAGT & 195 \\
\hline$R R A G B$ & GCCCATTGGAATGTTCTTGT & GCATCACGCTGCTCTTTACA & 217 \\
\hline STEAP1 & СTCTGGGAATTGTGGGATTG & GGCAAAAATCAATGCGTGTA & 158 \\
\hline TCEAL3 & CGAGGCCTAAAAAGGAGGAG & GGCTTTTCTTCCTCGTCTGA & 177 \\
\hline$T G M 2$ & AGCTACCTGCTGGCTGAGAG & GATCTCCACCGTCTTCTGCT & 195 \\
\hline BEXI & ACCAGCCCTTCTGCAGGT & TTTCTTGGTTGGCATTTTCC & 161 \\
\hline$C B S$ & GTAATCCTGGGAATGGTGAC & CTCCAGGATGTGCGAGAG & 153 \\
\hline$C C N B 1$ & GGCCAAATACCTGATGGAAC & GGTGCTGCATAACTGGAAGA & 182 \\
\hline STK6 & TGGTCAGTACATGCTCCATC & CTTGGTATGTGTTTGCCTCA & 178 \\
\hline DSIPI & TGGTGGCCATAGACAACAAG & CAGGGTCTTCAACAGGGTGT & 161 \\
\hline PTTG1 & TGCCTCTCATGATCCTTGAC & AAACAGGTGGCAATTCAACA & 159 \\
\hline PTTG3 & TCAAACAAAAACAGCCAAGC & GATGTGCAATCTGGTGCTCT & 174 \\
\hline$\beta$-actin & ATCATGTTTGAGACCTTCAA & CATCTCTTGCTCGAAGTCCA & 318 \\
\hline GAPDH & GTGAAGGTCGGAGTCAACG & GGTGAAGACGCCAGTGGACTC & 300 \\
\hline
\end{tabular}

antibody, Multi Link Swine anti-goat, -mouse or -rabbit (Dako), bound antibodies were visualized using DAB+ (Dako). The evaluation was performed by one experienced neuropathologist (C.Ö.) using conventional light microscopy. Multiple representative areas from each tumor sample were evaluated. Positivity in tumor cells was recorded, and a proportion was estimated. The positivity was classified as $1+$, low; 2+, moderate; and 3+, high. When significant cell to cell variation was observed, more than one level was recorded. Areas with rim-artefacts or bordering necrotic areas were not included in the estimation of positive tumor cells.

\section{Results}

Samples from the OSM-treated U1242MG cells were analyzed by microarray. Forty-one up-regulated and 26 down-regulated early response genes $(4 \mathrm{~h})$ were detected (Fig. 1). Twentyfour of the up-regulated early response genes continued to have an early expression $14 \mathrm{~h}$ after stimulation and 18 of them remained up-regulated after $24 \mathrm{~h}$. Ten of the genes that were down-regulated $4 \mathrm{~h}$ after stimulation were also downregulated after $14 \mathrm{~h}$ and 8 of them remained down-regulated after $24 \mathrm{~h}$. The total amount of differentially expressed genes peaked at $14 \mathrm{~h}$, with 86 up-regulated and 116 down-regulated genes. Twenty-four hours after addition of OSM, the number of up-regulated genes was 60 and the down-regulated genes were 102. Twelve up-regulated and seven down-regulated genes were selected for further analysis (Tables II and III). The selection was based on intensity of expression, level of

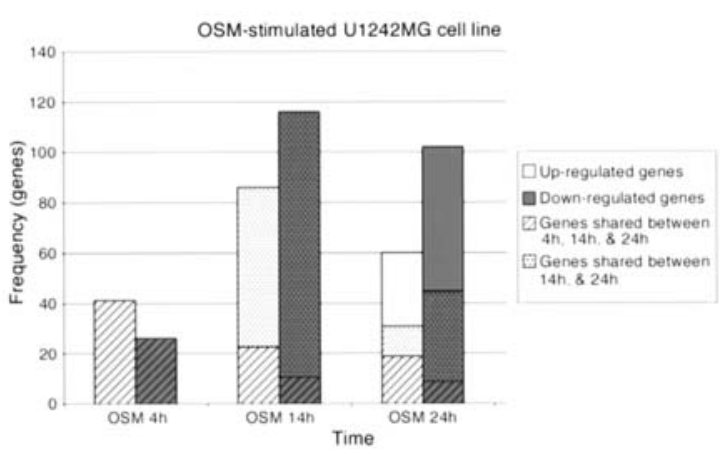

Figure 1. The total number of oncostatin M-induced genes at three different time-points $(4,14$ and $24 \mathrm{~h})$. Each time-point is divided into up- and downregulated genes. The groups of late gene expression (14 and $24 \mathrm{~h}$ ) visualize shared genes between the different time-points.

up/down-regulation and biological function. The expression pattern of the selected genes was further analyzed and confirmed by QPCR (Tables II and III). Verified genes were then searched for putative STAT binding sites, upstream and downstream of the transcription start site. Putative STAT binding sites were found in 10 out of 12 up-regulated and 5 out of 7 down-regulated genes (Tables II and III). No correlation was found between up/down-regulation of genes and the localization of putative STAT-binding sites.

Western blot analyses showed high levels of CHI3L1 protein after OSM stimulation in three glioma cell lines as well as in NHA (Fig. 2). 
Table II. Genes up-regulated after OSM stimulation.

\begin{tabular}{|c|c|c|c|c|}
\hline Gene name & $\begin{array}{l}\text { Times up-regulated } \\
\text { Array } 4 \mathrm{~h} / \mathrm{PCR} 4 \mathrm{~h}\end{array}$ & $\begin{array}{l}\text { Times up-regulated } \\
\text { Array } 14 \mathrm{~h} / \mathrm{PCR} 14 \mathrm{~h}\end{array}$ & $\begin{array}{l}\text { Times up-regulated } \\
\text { Array } 24 \mathrm{~h} / \mathrm{PCR} 24 \mathrm{~h}\end{array}$ & $\begin{array}{l}\text { Location of putative STAT binding } \\
\text { sites }^{\mathrm{a}}\end{array}$ \\
\hline CHI3L1 & $4.24^{\mathrm{b}} / 10.20$ & $10.99 / 25.11$ & $10.16 / 36.76$ & $-677,-32$ \\
\hline EPAS1 & $1.43^{\mathrm{b}} / 2.76$ & $2.3 / 12.06$ & $2.07 / 8.75$ & None \\
\hline GRIK2 & $5.05 / 2.48$ & $13.1 / 2.79$ & $5.08^{\mathrm{b}} / 3.43$ & $+837^{\mathrm{c}},+884^{\mathrm{c}},+1031^{\mathrm{c}}$ \\
\hline$I L 1 R 1$ & $2.12^{\mathrm{b}} / 3.99$ & $2.07 / 4.06$ & $2.73 / 4.07$ & $-718,-538,+807^{c}$ \\
\hline$M A P 2 K 2$ & $2.18 / 1.43$ & $2.50 / 1.45$ & $2.03 / 1.23$ & $+1706^{\mathrm{c}}$ \\
\hline$M T 2 A$ & $1.09^{\mathrm{b}} / 3.72$ & $1.84^{\mathrm{b}} / 8.86$ & $2.31 / 9.68$ & -193 \\
\hline$P L A U$ & $2.63 / 7.94$ & $5.76 / 32.06$ & $4.00 / 15.73$ & $-829,-767,-169$ \\
\hline RECK & $1.50^{\mathrm{b}} / 1.28$ & $1.70^{\mathrm{b}} / 2.19$ & $2.37 / 2.31$ & $+1538^{\mathrm{c}}$ \\
\hline$R R A G B$ & $1.12^{\mathrm{b} / 2.46}$ & $3.57 / 2.55$ & $3.69 / 2.81$ & None \\
\hline STEAP1 & $2.18^{\mathrm{b}} / 1.86$ & $2.38 / 6.74$ & $2.89 / 5.72$ & $-750,+1940^{c}$ \\
\hline TCEAL3 & $2.31^{\mathrm{b}} / 1.19$ & $0.74^{\mathrm{b}} / 1.70$ & $2.15 / 1.49$ & $-480,-480,+253^{c}$ \\
\hline$T G M 2$ & $3.94^{\mathrm{b}} / 1.14$ & $7.68 / 17.12$ & $13.63 / 11.84$ & $+615^{\mathrm{c}},+1259^{\mathrm{c}},+1260^{\mathrm{c}},+1396^{\mathrm{c}},+1798^{\mathrm{c}}$ \\
\hline
\end{tabular}

${ }^{\mathrm{a}}$ As number of nucleotides upstream (-) or downstream (+) of the transcription start site. 'Intensity $<75$. ${ }^{\mathrm{c}}$ First intron.

Table III. Genes down-regulated after OSM stimulation.

\begin{tabular}{|c|c|c|c|c|}
\hline Gene name & $\begin{array}{c}\text { Times down-regulated } \\
\text { Array } 4 \text { h/PCR } 4 \mathrm{~h}\end{array}$ & $\begin{array}{l}\text { Times down-regulated } \\
\text { Array } 14 \text { h/PCR } 14 \text { h }\end{array}$ & $\begin{array}{l}\text { Times down-regulated } \\
\text { Array } 24 \text { h/PCR } 24 \mathrm{~h}\end{array}$ & $\begin{array}{l}\text { Location of putative } \\
\text { STAT binding sites }\end{array}$ \\
\hline$B E X 1$ & $1.54^{\mathrm{b}} / 1.28$ & $4.00 / 2.56$ & $4.17 / 3.70$ & None \\
\hline$C B S$ & $2.08^{\mathrm{b}} / 2.38$ & $1.79^{\mathrm{b}} / 1.37$ & $3.13 / 3.23$ & $+34^{\mathrm{c}},+1477^{\mathrm{d}},+1582^{\mathrm{d}}$ \\
\hline$C C N B 1$ & $2.32 / 2.70$ & $2.70 / 2.56$ & $3.23 / 3.03$ & $-440,+531^{\mathrm{d}},+531^{\mathrm{d}}$ \\
\hline STK6 & $3.03 / 3.13$ & $3.33 / 3.33$ & $3.70 / 4.35$ & None \\
\hline DSIPI & $2.63^{\mathrm{b}} / 2,63$ & $2.38 / 2.44$ & $3.23 / 4.17$ & -848 \\
\hline PTTG1 & $1.82^{\mathrm{b}} / 2.38$ & $4.17 / 3.13$ & $4.35 / 2.22$ & $-621,-176,-176$ \\
\hline PTTG3 & $2.17^{\mathrm{b}} / 1.56$ & $3.23 / 2.94$ & $2.22 / 3.03$ & $-371,-332,-331$ \\
\hline
\end{tabular}

${ }^{\mathrm{a}}$ As number of nucleotides upstream (-) or downstream (+) of the transcription start site. ${ }^{\mathrm{b}}$ Intensity $<75 .{ }^{\mathrm{c}}$ First exon. ${ }^{\mathrm{d}}$ First intron.

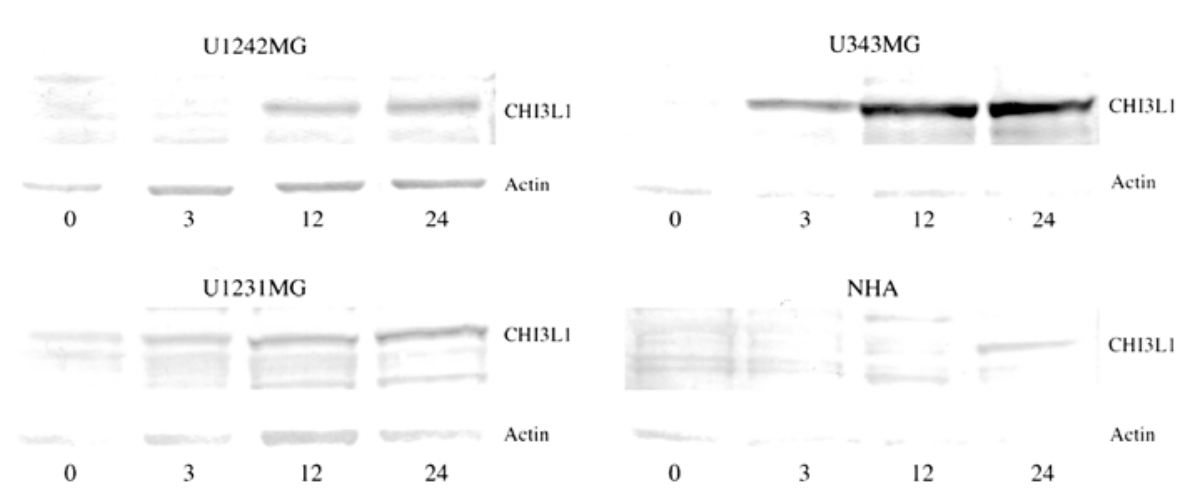

Figure 2. U1242MG, U343MG, U1231MG and NHA were stimulated by OSM. CHI3L1 protein was detected by Western blotting at 0,3, 12 and $24 \mathrm{~h}$ after stimulation. Actin was used as control.

IHC showed CHI3L1, PLAU and EPAS1 to be expressed in all tumors. No obvious correlation between IHC data and tumor type or grade could be found. A higher amount of EPAS1 was detected in tumors from older patients (Table IV). 
Table IV. Clinicopathologic data regarding cases stained immunohistochemically with antibodies against CHI3L1, PLAU and EPAS1.

\begin{tabular}{|c|c|c|c|c|c|c|c|c|}
\hline Case no. & $\begin{array}{l}\text { Age at surgery } \\
\text { (years) }\end{array}$ & $\begin{array}{l}\text { Sex } \\
(\mathrm{M} / \mathrm{F})\end{array}$ & Diagnosis & Grade & Clinical information & CHI3L1 & PLAU & EPAS1 \\
\hline 1 & 62 & $\mathrm{~F}$ & GBM & IV & $\begin{array}{c}\text { Primary surgery/ } \\
\text { clinically de novo GBM }\end{array}$ & $90 \%, 1-2+$ & $100 \%, 2-3+$ & $30 \%, 1+$ \\
\hline 2 & 62 & $\mathrm{~F}$ & GBM & IV & $\begin{array}{c}\text { Primary surgery/ } \\
\text { clinically de novo GBM }\end{array}$ & $60 \%, 1+$ & $100 \%, 1-2+$ & $30 \%, 1+$ \\
\hline 3 & 54 & M & GBM & IV & $\begin{array}{c}\text { Primary surgery/ } \\
\text { clinically de novo GBM }\end{array}$ & $90 \%, 2-3+$ & $90 \%, 1+$ & $30 \%, 1-2+$ \\
\hline 4 & 29 & M & GBM & IV & $\begin{array}{l}\text { Primary surgery/ } \\
\text { clinically de novo GBM }\end{array}$ & $50 \%, 1+$ & - & $90 \%, 1-2+$ \\
\hline 5 & 39 & M & GBM & IV & $\begin{array}{l}\text { Primary surgery/ } \\
\text { clinically de novo GBM }\end{array}$ & $90 \%, 1-2+$ & $100 \%, 1-3+$ & $80 \%,+1$ \\
\hline 6 & 66 & $\mathrm{~F}$ & GBM & IV & $\begin{array}{l}\text { Primary surgery/ } \\
\text { clinically de novo GBM }\end{array}$ & $95 \%, 1+$ & $100 \%, 2-3+$ & $90 \%, 1+$ \\
\hline 7 & 50 & M & GBM & IV & $\begin{array}{l}\text { Primary surgery/ } \\
\text { clinically de novo GBM }\end{array}$ & $95 \%, 1-2+$ & $100 \%, 1-2+$ & $40 \%, 1+$ \\
\hline 8 & 49 & $\mathrm{~F}$ & Anaplastic astrocytoma & III & Primary surgery & - & $95 \%, 2+$ & $30 \%, 1+$ \\
\hline 9 & 37 & M & Anaplastic astrocytoma & III & Primary surgery & $80 \%, 1+$ & $100 \%, 2-3+$ & $80 \%, 2+$ \\
\hline 10 & 9 & M & Anaplastic astrocytoma & III & $\begin{array}{l}\text { Surgery for diffuse astrocytoma, } \\
\text { grade II at age of } 7\end{array}$ & $90 \%, 1+$ & $90 \%, 1-2+$ & $20 \%, 1+$ \\
\hline 11 & 6 & M & Diffuse astrocytoma & II & Primary surgery & $90 \%, 1+$ & $70 \%, 1+$ & $25 \%, 1-2+$ \\
\hline 12 & 49 & M & Pilocytic astrocytoma & I & Primary surgery & $90 \%, 2+$ & $100 \%, 2-3+$ & $95 \%, 2+$ \\
\hline 13 & 12 & $\mathrm{~K}$ & Pilocytic astrocytoma & I & Primary surgery & $40 \%, 1+$ & $95 \%, 1-2+$ & $10 \%, 1+$ \\
\hline 14 & 8 & $\mathrm{~F}$ & Pilocytic astrocytoma & I & Primary surgery & $90 \%, 1+$ & $90 \%, 1-2+5$ & $-10 \%, 1+$ \\
\hline 15 & 64 & $\mathrm{~F}$ & Atypical meningioma & II & Primary surgery & $95 \%, 1+$ & $100 \%, 2-3+$ & $10 \%, 1+$ \\
\hline
\end{tabular}

Diagnoses are according to the WHO classification. Findings are classified as proportion (\%) of positive tumor cell-like cells and staining intensity from 1 to 3 , where 1 is weak and 3 is strong. GBM, glioblastoma multiforme.

\section{Discussion}

We have previously reported OSM to be expressed in many brain tumor types and that the cytokine is produced by tumor cells (6). Further analysis showed that the tumor cells have functional OSM receptors and signal transduction systems, but the effects of OSM expression on proliferation, apoptosis and migration in brain tumors remain unclear $(7,14,20,21)$. In this study we used a genome wide microarray analysis to investigate the expression patterns of OSM responsive genes in U1242MG. Differentially expressed genes were confirmed with QPCR. The gene expression varied between the time points, supposedly due to a chain of direct and indirect regulatory events. As little is known about which genes are immediate targets for OSM-induced JAK/STAT signaling, it was of particular interest to identify early OSM response genes $(4 \mathrm{~h})$. Therefore, we searched the sequence near the transcription start sites of identified response genes for putative STAT binding sites. Such binding sites were found upstream, as well as downstream, of the transcription start sites in 10 out of 12 up-regulated genes and in 5 out of 7 down-regulated genes. These genes may be considered as primary OSM targets. For up- or down-regulated genes lacking putative STAT binding sites, the change in expression could be induced by other signaling pathways, such as the MAPK cascade (11).

In this investigation $C H I 3 L 1$ (chitinase-like protein 1), aka $Y K L-40, P L A U$ (plasminogen activator of urokinase) aka $U P A$ and $M T 2 A$ (metallothionein 2A) were highly upregulated after OSM stimulation. They all contain putative STAT binding sites upstream of their transcription start sites, suggesting these genes to be direct targets for OSM. Western blot analysis confirmed $C H I 3 L 1$, the most up-regulated gene, to be induced by OSM in three glioma cell lines and in NHA. This further supports our hypothesis that CHI3L1 is an early OSM response gene.

Several of the early response genes are interesting in the context of tumor genesis. CHI3L1 and PLAU are considered to be involved in cell migration and degradation and remodeling of extracellular matrix (22-26). PLAU has also been implicated in enhanced cell proliferation and modulation of cell adhesion (27). MT2A is a member of the metallothionein (MT) family of ion-binding proteins which have been linked with enhanced cell proliferation in several types of cancer (28). MT has also been reported as a potential negative regulator of apoptosis 
and to be overexpressed in a variety of neoplasms, including brain tumors $(29,30)$. The abnormal regulation of proliferation, apoptosis and extracellular matrix degradation is prominent in GBM.

The IHC results presented in this study showed CHI3LI to be widely expressed in brain tumors. This is supported by earlier IHC studies that have shown $\mathrm{CHI} 3 \mathrm{~L} 1$ to be expressed by the tumor cells in GBM $(31,32)$. CHI3L1 expression has been reported to correlate with worse clinical outcome in GBM and elevated serum levels of CHI3L1 have been observed in patients with different types of neoplasms, including GBM (31-37). PLAU together with its receptor (UPAR) has been shown to be expressed in GBM, but not in low-grade astrocytomas and non-neoplastic brain tissue $(25,38)$. This is in accordance with an earlier study that has reported that tumor grade and patient survival correlated with PLAU expression (39). In this study IHC showed expression of PLAU in both high- and low-grade astrocytomas. Taken together, the IHC results show that the OSM responsive genes CHI3L1 and $P L A U$ are expressed in GBM and may be of importance for the invasiveness of this tumor.

Among the early response down-regulated genes, we found $C C N B 1$ (cyclin B1) and two variants of PTTG (pituitary tumor transforming gene); PTTG1 and PTTG3. These genes all contained putative STAT binding sites, indicating that they may be regulated by STAT proteins. $C C N B 1$ is an essential regulator of the cell cycle at the $\mathrm{G} 2 / \mathrm{M}$ transition. $P T T G$ is an oncogene that participates in several key cellular events such as mitosis, cell cycle progression, DNA repair and apoptosis (40). CCNB1, PTTG1 and PTTG3 have growth promoting functions, and down-regulation is associated with decreased cell proliferation. This is also supported by an earlier report that OSM inhibited human glioma cell proliferation via the gp130/OSMRß (7). However, in our previous study no significant effects on cell proliferation were found (14). Thus, OSM up-regulates some growth promoting genes, whereas others are down-regulated. This may explain the inconsistent reports on OSM effects in astrocytoma cells $(7,14,20,21)$.

EPAS1 (endothelial PAS domain protein 1) aka HIF $2 \alpha$ was up-regulated early after OSM stimulation. It is likely that EPAS1 was induced by OSM, independent of the JAK/ STAT pathway since no STAT binding sites were found in the region close to the transcription start site. It might be noteworthy, that in the IHC investigation, expression of EPAS1 in pilocytic astrocytomas was found to be lower in tumors from children compared to tumors from adult patients (5-10\% and 95\% respectively). EPAS1 encodes a transcription factor that is expressed preferentially in vascular endothelial cells and high expression has been reported in several human malignances $(41,42)$. EPAS1 is important for tumor adaptation to hypoxia and transactivates the transcription of VEGF (vascular endothelial growth factor), an important angiogenic factor, reported to increase in astroglioma cell lines after OSM treatment (43). These observations suggest that OSM may be involved in angiogenesis through induction of EPAS1 and $V E G F$.

STEAP1 (six-transmembrane epithelial antigen of the prostate 1) was found among the up-regulated genes with a later response to OSM stimulation. Since the response was late $(14 \mathrm{~h})$ the up-regulation probably depends on secondary events. STEAPl was reported to encode a cell surface antigen located at cell-cell junctions, but its exact function is unknown. However, it could be involved in the malignant process as it is reported to be up-regulated in human prostate tumors and in many cancer cell lines (44).

Expression of both $O S M$ and CHI3L1 in glioma cells has been shown to be induced by a wide range of cellular stress conditions, i.e. hypoxia and ionizing radiation $(2,3,45)$. OSM may act as a coordinating stress response factor that activates downstream effector genes, among them CHI3L1. Taken together with our data, these observations suggest that OSM production is a part of stress response and healing processes that also has an important role in tumor genesis.

In summary, using two independent methods, microarray and QPCR, we have shown that OSM regulates the expression of 19 genes (Tables II and III) in a glioma cell line. The induction of CHI3L1 was also confirmed by Western blotting in four glioma cell lines and normal human astrocytes. The expression of OSM up-regulated genes, CHI3L1, PLAU and EPAS1, were analyzed by IHC in a panel of astrocytomas.

We conclude that OSM might contribute to tumor development and progression by inducing genes involved in matrix remodeling, migration, proliferation control and angiogenesis.

\section{Acknowledgements}

This study was supported by grants from the Inga-Britt and Arne Lundberg Research Foundation, the Swedish Cancer Society, the Children's Cancer Foundation, the Assar Gabrielsson Research Foundation, the King Gustav V Jubilee Clinic Cancer Research Foundation, the Sahlgrenska University Hospital Foundations, the Wilhelm and Martina Lundgren Science Foundation and the Swedish Society for Medical Research.

\section{References}

1. Ruprecht K, Kuhlmann T, Seif F, et al: Effects of oncostatin M on human cerebral endothelial cells and expression in inflammatory brain lesions. J Neuropathol Exp Neurol 60: 1087-1098, 2001.

2. Jankowsky JL and Patterson PH: Differential regulation of cytokine expression following pilocarpine-induced seizure. Exp Neurol 159: 333-346, 1999.

3. Ito Y, Yamamoto M, Li M, et al: Temporal expression of mRNAs for neuropoietic cytokines, interleukin-11 (IL-11), oncostatin M (OSM), cardiotrophin-1 (CT-1) and their receptors (IL-11Ralpha and OSMRbeta) in peripheral nerve injury. Neurochem Res 25: 1113-1118, 2000.

4. Hasegawa M, Sato S, Ihn H and Takehara K: Enhanced production of interleukin-6 (IL-6), oncostatin M and soluble IL-6 receptor by cultured peripheral blood mononuclear cells from patients with systemic sclerosis. Rheumatology 38: 612-617, 1999.

5. Ensoli F, Fiorelli V, DeCristofaro M, et al: Inflammatory cytokines and HIV-1-associated neurodegeneration: oncostatin-M produced by mononuclear cells from HIV-1-infected individuals induces apoptosis of primary neurons. J Immunol 162: 6268-6277, 1999.

6. Lilja A, Nordborg C, Brun A, Salford LG and Aman P: Expression of the IL-6 family cytokines in human brain tumors. Int J Oncol 19: 495-499, 2001.

7. Chen SH, Gillespie GY and Benveniste EN: Divergent effects of oncostatin $\mathrm{M}$ on astroglioma cells: influence on cell proliferation, invasion, and expression of matrix metalloproteinases. Glia 53: 191-200, 2006.

8. Taga T and Kishimoto T: Gp130 and the interleukin- 6 family of cytokines. Annu Rev Immunol 15: 797-819, 1997. 
9. Heinrich PC, Behrmann I, Haan S, Hermanns HM, Muller-Newen G and Schaper F: Principles of interleukin (IL)6-type cytokine signalling and its regulation. Biochem J 374: $1-20,2003$.

10. Schaefer LK, Menter DG and Schaefer TS: Activation of stat3 and stat1 DNA binding and transcriptional activity in human brain tumour cell lines by gp130 cytokines. Cell Signal 12: $143-151,2000$

11. Van Wagoner NJ, Choi C, Repovic P and Benveniste EN: Oncostatin $M$ regulation of interleukin-6 expression in astrocytes: biphasic regulation involving the mitogen-activated protein kinases ERK1/2 and p38. J Neurochem 75: 563-575, 2000 .

12. Gearing DP and Bruce AG: Oncostatin M binds the highaffinity leukemia inhibitory factor receptor. New Biol 4: 61-65, 1992.

13. Stahl N, Farruggella TJ, Boulton TG, Zhong Z, Darnell JE Jr and Yancopoulos GD: Choice of STATs and other substrates specified by modular tyrosine-based motifs in cytokine receptors. Science 267: 1349-1353, 1995.

14. Krona A, Jarnum S, Salford LG, Widegren B and Aman P: Oncostatin M signaling in human glioma cell lines. Oncol Rep 13: 807-811, 2005.

15. Zhang F, Li C, Halfter H and Liu J: Delineating an oncostatin M-activated STAT3 signaling pathway that coordinates the expression of genes involved in cell cycle regulation and extracellular matrix deposition of MCF-7 cells. Oncogene 22: 894-905, 2003

16. Saal LH, Troein C, Vallon-Christersson J, Gruvberger S, Borg A and Peterson C: BioArray Software Environment (BASE): a platform for comprehensive management and analysis of microarray data. Genome Biol 3: SOFTWARE0003, 2002.

17. Yang YH, Dudoit S, Luu P, et al: Normalization for cDNA microarray data: a robust composite method addressing single and multiple slide systematic variation. Nucleic Acids Res 30: e15, 2002 .

18. Vandesompele J, De Preter K, Pattyn F, et al: Accurate normalization of real-time quantitative RT-PCR data by geometric averaging of multiple internal control genes. Genome Biol 3: RESEARCH0034, 2002.

19. Seidel HM, Milocco LH, Lamb P, Darnell JE Jr, Stein RB and Rosen J: Spacing of palindromic half sites as a determinant of selective STAT (signal transducers and activators of transcription) DNA binding and transcriptional activity. Proc Natl Acad Sci USA 92: 3041-3045, 1995.

20. Halfter H, Postert C, Friedrich M, Ringelstein EB and Stogbauer F: Activation of the Jak-Stat- and MAPK-pathways by oncostatin $\mathrm{M}$ is not sufficient to cause growth inhibition of human glioma cells. Brain Res Mol Brain Res 80: 198-206, 2000.

21. Halfter H, Lotfi R, Westermann R, Young P, Ringelstein EB and Stogbauer FT: Inhibition of growth and induction of differentiation of glioma cell lines by oncostatin M (OSM). Growth Factors 15: 135-147, 1998.

22. Malinda KM, Ponce L, Kleinman HK, Shackelton LM and Millis AJ: Gp38k, a protein synthesized by vascular smooth muscle cells, stimulates directional migration of human umbilical vein endothelial cells. Exp Cell Res 250: 168-173, 1999.

23. Boot RG, van Achterberg TA, van Aken BE, et al: Strong induction of members of the chitinase family of proteins in atherosclerosis: chitotriosidase and human cartilage gp-39 expressed in lesion macrophages. Arterioscler Thromb Vasc Biol 19: 687-694, 1999.

24. Hakala BE, White $\mathrm{C}$ and Recklies AD: Human cartilage gp-39, a major secretory product of articular chondrocytes and synovial cells, is a mammalian member of a chitinase protein family. J Biol Chem 268: 25803-25810, 1993.
25. Gladson CL, Pijuan-Thompson V, Olman MA, Gillespie GY and Yacoub IZ: Up-regulation of urokinase and urokinase receptor genes in malignant astrocytoma. Am J Pathol 146: 1150-1160, 1995

26. Choong PF and Nadesapillai AP: Urokinase plasminogen activator system: a multifunctional role in tumor progression and metastasis. Clin Orthop Relat Res: S46-S58, 2003.

27. Duffy MJ: The urokinase plasminogen activator system: role in malignancy. Curr Pharm Des 10: 39-49, 2004

28. Jin R, Chow VT, Tan PH, Dheen ST, Duan W and Bay BH: Metallothionein 2A expression is associated with cell proliferation in breast cancer. Carcinogenesis 23: 81-86, 2002.

29. Theocharis SE, Margeli AP, Klijanienko JT and Kouraklis GP Metallothionein expression in human neoplasia. Histopathology 45: 103-118, 2004.

30. Maier H, Jones C, Jasani B, et al: Metallothionein overexpression in human brain tumours. Acta Neuropathol 94: 599-604, 1997.

31. Nigro JM, Misra A, Zhang L, et al: Integrated array-comparative genomic hybridization and expression array profiles identify clinically relevant molecular subtypes of glioblastoma. Cancer Res 65: 1678-1686, 2005 .

32. Nutt CL, Betensky RA, Brower MA, Batchelor TT, Louis DN and Stemmer-Rachamimov AO: YKL-40 is a differential diagnostic marker for histologic subtypes of high-grade gliomas. Clin Cancer Res 11: 2258-2264, 2005.

33. Tanwar MK, Gilbert MR and Holland EC: Gene expression microarray analysis reveals YKL-40 to be a potential serum marker for malignant character in human glioma. Cancer Res 62: 4364-4368, 2002.

34. Cintin C, Johansen JS, Christensen IJ, Price PA, Sorensen S and Nielsen HJ: Serum YKL-40 and colorectal cancer. Br J Cancer 79: 1494-1499, 1999.

35. Jensen BV, Johansen JS and Price PA: High levels of serum HER-2/neu and YKL-40 independently reflect aggressiveness of metastatic breast cancer. Clin Cancer Res 9: 4423-4434, 2003.

36. Dupont J, Tanwar MK, Thaler HT, et al: Early detection and prognosis of ovarian cancer using serum YKL-40. J Clin Oncol 22: 3330-3339, 2004

37. Johansen JS, Drivsholm L, Price PA and Christensen IJ: High serum YKL-40 level in patients with small cell lung cancer is related to early death. Lung Cancer 46: 333-340, 2004.

38. Yamamoto M, Sawaya R, Mohanam S, et al: Expression and localization of urokinase-type plasminogen activator in human astrocytomas in vivo. Cancer Res 54: 3656-3661, 1994

39. Hsu DW, Efird JT and Hedley-Whyte ET: Prognostic role of urokinase-type plasminogen activator in human gliomas. Am J Pathol 147: 114-123, 1995.

40. Tfelt-Hansen J, Kanuparthi D and Chattopadhyay N: The emerging role of pituitary tumor transforming gene in tumorigenesis. Clin Med Res 4: 130-137, 2006.

41. Talks KL, Turley H, Gatter KC, et al: The expression and distribution of the hypoxia-inducible factors HIF-1alpha and HIF-2alpha in normal human tissues, cancers, and tumorassociated macrophages. Am J Pathol 157: 411-421, 2000.

42. Tian H, McKnight SL and Russell DW: Endothelial PAS domain protein 1 (EPAS1), a transcription factor selectively expressed in endothelial cells. Genes Dev 11: 72-82, 1997.

43. Repovic P, Fears CY, Gladson CL and Benveniste EN: Oncostatin-M induction of vascular endothelial growth factor expression in astroglioma cells. Oncogene 22: 8117-8124, 2003.

44. Hubert RS, Vivanco I, Chen E, et al: STEAP: a prostate-specific cell-surface antigen highly expressed in human prostate tumors. Proc Natl Acad Sci USA 96: 14523-14528, 1999.

45. Junker N, Johansen JS, Hansen LT, Lund EL and Kristjansen PE Regulation of YKL-40 expression during genotoxic or microenvironmental stress in human glioblastoma cells. Cancer Sci 96: 183-190, 2005. 